\title{
Dietary supplementation of autolysed yeast enhances growth, liver functionality and intestinal morphology in African catfish
}

by Adeoye, A.A., Obasa, S.O., Fawole, F.J., Wan, A.H. and Davies, S.J.

Copyright, publisher and additional information: this is the author accepted manuscript. The final published version (version of record) is available online via Wiley. This article may be used for non-commercial purposes in accordance with Wiley Terms and Conditions for Self-Archiving.

Please refer to any applicable terms of use of the publisher.

DOI: https://doi.org/10.1111/anu.13036
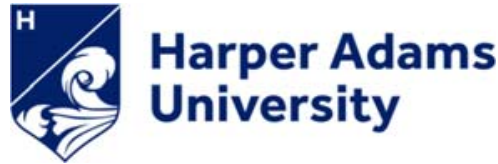


\section{Dietary supplementation of autolysed brewer's yeast enhances performance and intestinal morphology in African catfish, Clarias gariepinus}

(Running title: Autolysed yeast in African catfish)

\section{Acknowledgement}

The authors would like to acknowledge that Leiber GmbH, Bramsche, Germany supplied the autolysed brewer's yeast (Leiber $\mathrm{CeFi}^{\circledR}$ Pro) for the study and partially funded the sample analyses

\section{Abstract}

A feeding trial was conducted to evaluate the potential of dietary supplementation of autolysed brewer's yeast (AY) on African catfish. The catfish $\left(22.5 \pm 1.15 \mathrm{~g}\right.$ fish $^{-1}, 20$ fish 33L tank $\left.\mathrm{L}^{-1}\right)$ were fed with either of diets (390 $\mathrm{g} \mathrm{kg}^{-1}$ crude protein, $140 \mathrm{~g} \mathrm{~kg}^{-1}$ lipid) supplemented with 0 , 3,6 or $10 \mathrm{~g} \mathrm{~kg}^{-1} \mathrm{AY}(\mathrm{n}=3)$. After 49 days of feeding, the final body weight and metabolic growth rate of the catfish fed $3 \mathrm{~g} \mathrm{~kg}^{-1} \mathrm{AY}$ (3-AY) diet was higher than those fed the control $\operatorname{diet}(P<0.05)$. The lowest level $(P<0.05)$ of alanine transaminase was detected in the blood of the catfish fed 3-AY diet. The mid-intestinal histology of the catfish revealed no significant difference $(P>0.05)$ in intestinal perimeter ratio. However, an elevated $(P<0.05)$ abundance of goblet cells and intraepithelial leucocytes were found in the intestine of catfish fed 3, 6 and $10 \mathrm{~g} \mathrm{~kg}^{-1}$ AY diets, with the highest level of abundance recorded in the mid-intestine of the catfish fed 3-AY diet. The results suggest that dietary $3 \mathrm{~g} \mathrm{~kg}^{-1}$ autolysed brewer's yeast supplementation improve growth performance of African catfish without deleterious effect on liver functionality and gut morphology.

Keywords: African catfish, Brewer's yeast, functional feeds, gut morphology, hepatic function 


\subsection{Introduction}

As the global human population continues to rise with an expected $>8$ billion in 2030, there will be a need to further develop sustainable food production systems to meet the increase in food demand (United Nations, 2017). In 2016, global fish production was estimated to be >171 million tonnes, with farmed fish representing $\sim 50 \%$ of the quantity produced (FAO, 2018). The fish aquaculture sector is expected to continue to grow in response to the global food challenge. However, the growth in the aquaculture industry is often hindered by problems associated with intensification practices and leading to suboptimal growing conditions. Some of these issues include water quality, overcrowding and nutrient imbalance. These stressful conditions can have the potential to compromise fish health and consequently lead to the fish being prone to infection and disease by opportunistic pathogens (Bondad-Reantaso et al., 2005).

The concept of immunonutrition is the potential of modulating the immune system through dietary means (Nakagawa et al., 2007; Kiron, 2012) and can be achieved through dietary supplementation of immunostimulants (Dawood et al., 2018). Unicellular brewer's yeast (Saccharomyces cerevisiae) can have immunostimulatory and bioactivity effects and has been shown to enhance growth performance, health and immunity in farmed fish species (Shurson, 2018). In addition to its relatively high protein, energy and micronutrients content (e.g. vitamins and trace elements), brewer's yeast also possesses bioactive $\beta$-glucans, mannanoligosaccharides and nucleotides (Huyben et al., 2017; Xue et al., 2017; Shurson, 2018). The growth and health benefits of brewer's yeast and its by-products have been reported in a number of farmed fish species. These include Labeo rohita (Amir et al., 2018), rainbow trout (Oncorhynchus mykiss, Huyben et al., 2017; Jin et al., 2018), turbot (Scophthalmus maximus, Librán-Pérez et al., 2018), gilthead sea bream (Sparus aurata, Dimitroglou et al., 2010; Gultepe et al., 2011; Dawood et al., 2017), Nile tilapia (Sado et al., 2008; Ozório et al., 2012; Pilarski et al., 2017; Hassaan et al., 2018), largemouth bass (Micropterus salmoides, Zhou et al., 2018), Pacific white shrimp (Litopanaeus vannamei, Zhang et al., 2012; Qiu \& Davis, 2017; Jin et al., 2018), Jian carp (Cyprinus carpio var. Jian, Yuan et al., 2017), gibel carp (Carassius gibelio, Zhang et al., 2018), common carp (Cyprinus carpio, Momeni-Moghaddam et al., 2015), hybrid striped bass (Morone chrysops x Morone saxatilis, Li \& Gatlin, 2003), giant freshwater prawn (Macrobrachium rosenbergii, Prasad et al., 2013), Thai panga (Pangasianodon hypophthalmus $\times$ Pangasius bocourti, Pongpet et al., 2016), channel catfish (Ictalurus punctatus, Peterson et al., 2012), European seabass (Dicentrarchus labrax, 
Torrecillas et al., 2007, 2011, 2015; Salem et al., 2016) and pacu (Piaractus mesopotamicus, Sado et al., 2014). However, there is limited knowledge on the effects of brewer's yeast and its derivatives on farmed African catfish (C. gariepinus). This is with the exception of studies that were carried out on brewer's yeast as an alternative protein source in African catfish diets (Hoffman et al.,1997; Ezenwaji et al., 2012; Solomon et al., 2017). To this end, the current study evaluated the effects dietary supplementation of a commercial autolysed brewer's yeast (Leiber $\mathrm{CeFi}^{\circledR}$ Pro) has on growth performance, health and intestinal morphology in African catfish (C. gariepinus). The information generated would have economical importance in the sub-Saharan Africa nations (e.g. Nigeria, Ghana and Uganda), as it reperesents $91 \%$ of the world's farmed African catfish production with a value of over USD 632 million in 2017 (FAO, 2019).

\subsection{Materials and Methods}

\subsection{Experimental design and diet preparation}

The feeding trial was performed in a freshwater flow-through aquaculture system $\left(2.5 \mathrm{~L} \mathrm{~min}^{-1}\right.$ flow rate into the fish tank) at the Department of Aquaculture and Fisheries Management, Federal University of Agriculture, Abeokuta, Nigeria. The flow-through system consists of 12 tanks (33 L) and was supplied by a freshwater spring. African catfish (C. gariepinus) were sourced from a local fish hatchery (Motherhood Fish Farm, Abeokuta, Nigeria) and were acclimated into the system for two weeks prior to the start of the feeding trial. For each tank, 20 fish were randomly stocked to give an average mean weight of $22.5 \pm 1.15 \mathrm{~g} \mathrm{fish}^{-1}$. The photoperiod ( $17 \mathrm{~h}: 7 \mathrm{~h}$, light: dark) and water temperature $\left(29 \pm 0.29^{\circ} \mathrm{C}\right)$ were maintained at ambient condition. Water quality parameters were monitored weekly; pH, 6.85 \pm 0.34 (HI98107 pHep ${ }^{\circledR}$, Hanna Instruments, Leighton Buzzard, UK); dissolved oxygen, >5 mg L ${ }^{-1}$ (HI3810, Hanna Instruments, Leighton Buzzard, UK) and total ammonia nitrogen, $0.14 \pm 0.1 \mathrm{mg} \mathrm{L}^{-1}$ (HI3824, Hanna Instruments, Leighton Buzzard, UK).

The autolysed brewer's yeast (Leiber $\mathrm{CeFi}^{\circledR}$ Pro) was supplied by Leiber $\mathrm{GmbH}$, Bramsche, Germany. The nutritional value of the autolysed brewer's yeast is shown in Table 1. Four isonitrogenous (390 $\mathrm{g} \mathrm{kg}^{-1}$ crude protein) and iso-lipidic (140 $\mathrm{g} \mathrm{kg}^{-1}$ lipid) diets were formulated with the inclusion of 3 (3-AY), 6 (6-AY) and 10 (10-AY) $\mathrm{g} \mathrm{kg}^{-1}$ autolysed brewer's yeast (AY) at the expense of shrimp meal (Table 2). The fourth diet was formulated without the inclusion of AY to give a basal comparison (Control). Production of the test diets involved mixing of the ingredients to give homogenous dough and subsequently cold extruded (flat die pelleting 
machine-CAPSFEED, Ibadan, Nigeria) to produce $2 \mathrm{~mm}$ diameter sinking pellets. The diets were oven dried at $60{ }^{\circ} \mathrm{C}$ for $12 \mathrm{~h}$. Dried diets were subsequently stored in airtight containers prior to use. Fish were fed with the test diets twice a day (0900 and 1600) to apparent satiation for 49 days.

Quality validation of the finished diets was performed through proximate analysis according to AOAC (2012) protocols and values are presented in Table 2. Moisture was determined by drying samples in oven set to $105^{\circ} \mathrm{C}$ until constant weight was achieved. Samples were transferred to desiccator to cool, re-weighed and moisture content determined. For ash analysis, samples were weighed and placed in muffle furnace at $550^{\circ} \mathrm{C}$ for $8 \mathrm{~h}$ until a light grey ash resulted. After cooling in desiccator, samples were re-weighed, and ash content was determined. The Soxhlet ether method was used for lipid analysis. The Kjeldahl method was used to determine the nitrogen content of the samples. The crude protein content was determined by multiplying the nitrogen by a factor of 6.25 for animal proteins and 5.95 for proteins of plant origin. All samples were analysed in triplicate.

\subsection{Growth, feed efficiency and somatic indices}

To assess the effects of the test diets on the fish, the following morphological parameters were measured: body weight (BW), full length (FL), liver weight (LW) and visceral weight (VW). In addition, growth performance, feed efficiency and somatic indices were calculated (Adeoye et al., 2016; Fawole et al., 2018).

Feed Intake, $\mathbf{F I}=$ Total feed consumed $(\mathrm{g}) /$ Number of fish harvested

Specific Growth Rate, SGR $=((\ln F B W-\ln I B W) / T) X 100$

where FBW = final body weight $(\mathrm{g})$ and IBW = initial body weight $(\mathrm{g})$

\section{Metabolic Growth Rate, MGR}

$=($ Net weight gain in $\mathrm{g}) /\left[\left\{(\mathrm{IBW} / 1000)^{0.8}+(\mathrm{FBW} / 1000)^{0.8}\right\} / 2\right] /$ feeding duration in days where FBW = final body weight $(\mathrm{g})$ and IBW = initial body weight $(\mathrm{g})$

\section{Feed Conversion Ratio, FCR $=F I / W G$}

where FI = feed intake $(\mathrm{g})$ and $\mathrm{WG}=$ wet weight gain $(\mathrm{g})$ 
where $\mathrm{WG}=$ wet weight gain $(\mathrm{g})$ and $\mathrm{PI}=$ protein ingested $(\mathrm{g})$

$$
\text { Hepatosomatic Index, HSI }=(L W / B W) X 100
$$

where $\mathrm{LW}=$ liver weight $(\mathrm{g})$ and $\mathrm{BW}=$ body weight $(\mathrm{g})$

\section{Viscerosomatic Index, VSI $=(V W / B W) X 100$}

where VW = visceral weight $(\mathrm{g})$

\section{Condition Factor, $\mathbf{K}=(100 X B W) / \llbracket T L \rrbracket \wedge 3$}

where $\mathrm{BW}=$ body weight $(\mathrm{g})$ and $\mathrm{TL}=$ total length $(\mathrm{cm})$

\section{Survival $=($ Total number of fish harvested $/$ total number of fish stocked $) \times 100$}

\subsection{Haematological-biochemical parameters}

At the end of the feeding trial, two fish per tank ( $n=6$ per treatment) were anaesthetised with clove oil at a concentration of $100 \mathrm{mg} \mathrm{L}^{-1}$ followed by cerebral percussion and disruption of the brain prior to sampling. Blood collection was carried out through the caudal arch using 25gauge needle and $1 \mathrm{~mL}$ syringe. Blood smears were prepared for determination of differential leucocytes count and additional blood was left to stand in a slanted position at room temperature to isolate serum. Packed cell volume, haemoglobin, erythrocyte blood cell count, leucocyte count, and differential leucocyte proportions were determined according to standard methods. Packed cell volume of the whole blood was assessed in triplicate using microhaematocrit method (Brown, 1980). Haemoglobin was determined using Drabkin's cyanide-ferricyanide solution (1/250 dilution factor) measured after 5 min of incubation using a spectrophotometer set to $540 \mathrm{~nm}$ wavelength and the haemoglobin levels $\left(\mathrm{g} \mathrm{dL}^{-1}\right)$ calculated using the following formula below.

Haemoglobin concentration $\left(\mathrm{g} \mathrm{dL}^{-1}\right)=$

$$
\frac{\text { Absorbance of sample }}{\text { Absorbance of standard }} X \text { Dilution factor }
$$

Enumeration of erythrocytes and leucocytes was conducted as described by Dacie and Lewis (1975). Twenty microliters of whole blood was mixed with $980 \mu \mathrm{L}$ of Dacies solution (1/50 dilution factor), mixed for 60 seconds to ensure a homogenous solution. A $5 \mu \mathrm{L}$ of the homogenous solution was aliquoted to haemacytometer and minimum of 500 cells counted for a ststistically valid data. Blood smears for differential leucocytes count were air-dried, fixed 
in methanol for $15 \mathrm{~min}$ and stained using May Grünwald stain (diluted 1:1 with Sorensen's

173 buffer, $\mathrm{pH}$ 6.8). The smears were then rinsed in Sorensen's buffer and counter stained with

174 Giemsa stain (diluted 1:9 with Sorensen's buffer, $\mathrm{pH}$ 6.8). After a final rinse in buffer, slides

175 were left to dry. Once dried, the slides were mounted in DPX. Neutrophil, lymphocytes,

176 basophil, eosinophil and monocytes were identified as described by Rowley (1990). A

177 minimum of 200 cells per sample were counted and the values expressed as percentage of the

178 total leucocytes. Mean corpuscular volume (MCV), mean corpuscular haemoglobin (MCH)

179 and mean corpuscular haemoglobin concentration (MCHC) were calculated as previously

180 described by Adeoye et al. (2016). The sera were centrifuged (3,000 g, $10 \mathrm{~min}$ at $\left.4{ }^{\circ} \mathrm{C}\right)$ and

181 transferred into another tube and kept at $-20{ }^{\circ} \mathrm{C}$ for immediate use. Serum aspartate

182 transaminase (AST), alanine transaminase (ALT) and alkaline phosphatase (ALP) were

183 estimated as described by Fawole et al. (2018) using a commercial kit (Randox Laboratories

184 Limited, Crumlin, United Kingdom).

185

186

\subsection{Intestinal histology}

187 At the end of the trial, two fish per tank ( $n=6$ per treatment) were sampled for mid-intestine 188 histological examination. The samples were fixed in $10 \%$ neutral buffered formalin and embedded in paraffin wax for sectioning. Sample sections were subsequently stained with haematoxylin and eosin and Periodic acid-Schiff stains. The mid-intestines were imaged using a light microscope (BX53, Olympus Life Science, Tokyo, Japan) and morphological measurements were carried out through ImageJ (version 1.51, National Institute of Health, Bethesda, Maryland, USA). The intestinal perimeter ratio (PR) was assessed as described in Adeoye et al. (2016). PR was calculated as the ratio between the internal perimeter (IP) of the intestinal lumen (villi and mucosal folding length) and the external perimeter (EP) of the intestine (PR = IP/ EP, arbitrary units, AU). The number of intraepithelial leucocytes (IELs) and goblet cells in the epithelium, across a standardized distance of $100 \mu \mathrm{m}$ (10 folds per specimen) was calculated by averaging the numbers from all specimens.

\subsection{Statistical analysis}

201 All data are presented as mean values and with its corresponding standard deviation. Data were analysed using one-way analysis of variance (ANOVA). Post-hoc multiple comparisons test was performed using Duncan's new multiple range test. Differences were considered significant for each parameter when $P<0.05$. 


\subsection{Results}

207

208

209

210

211

212

213

214

215

216

217

218

219

220

221

222

223

224

225

226

227

228

229

230

231

232

233

234

235

236

237

\subsection{Growth, feed efficiency and somatic indices}

From the 49 days feeding trial, the African catfish (C. gariepinus) growth performance, feed efficiency and somatic indices were assessed through FBW, SGR, MGR, FCR, PER, K-factor, HSI, VSI and survival (Table 3). At the end of the trial, the catfish fed with the test diets had increase in weight by up to 4.8-fold. It was observed that catfish FBW (15\%) and MGR (10 $\%$ ) had significantly increased in $3 \mathrm{~g} \mathrm{~kg}^{-1} \mathrm{AY}$ dietary inclusion level, when compared to the dietary control group $(P<0.05)$. The VSI was also significantly higher $(24 \%)$ among the catfish that were fed with $10 \mathrm{~g} \mathrm{~kg}^{-1} \mathrm{AY}$ supplementation than among those fed the control diet $(P<0.05)$. The dietary treatment did not have a significant effect on other parameters (FI, SGR, FCR, PER, K, HSI and survival) in the African catfish.

\subsection{Haemato-biochemical parameters}

The results of the haemato-biochemical parameters from the African catfish fed with the experimental diets are displayed in Table 4. No differences were observed between dietary treatments in any measured haematological parameters. However, the level of blood alanine transaminase (ALT) activity was found to be significantly lower in catfish fed either $3 \mathrm{~g} \mathrm{~kg}^{-1}$ or $6 \mathrm{~g} \mathrm{~kg}^{-1} \mathrm{AY}$ dietary supplementation, when compared with the control group $(P<0.05)$. The largest decrease in ALT activity was by $45 \%$ in $3 \mathrm{~g} \mathrm{~kg}^{-1} \mathrm{AY}$ dietary treatment, while $6 \mathrm{~g}$ $\mathrm{kg}^{-1} \mathrm{AY}$ inclusion gave only $39 \%$ reduction.

\subsection{Intestinal histology}

The mid-intestine of the African catfish fed each of the experimental diets was examined by light microscopy (Figure 1). The African catfish from all treatments showed intact epithelial barriers with extensive mucosal folds extending into the lumen. Each fold consisted of simple lamina propria with abundant intraepithelial leucocytes (IELs) and mucous-secreting goblet cells. There was no significant difference in the intestinal perimeter ratios of African catfish fed with AY supplemented diets $(P>0.05$, Table 5$)$. However, there was a significant increase in the abundance of goblet cells and IELs in the catfish intestine when fed with AY supplemented diets (i.e. $3 \mathrm{~g} \mathrm{~kg}^{-1}, 6 \mathrm{~g} \mathrm{~kg}^{-1}$ and $10 \mathrm{~g} \mathrm{~kg}^{-1} \mathrm{AY}$ diets). The highest increase was found in $6 \mathrm{~g} \mathrm{~kg}^{-1} \mathrm{AY}$ dietary group, with goblet cell and IELs levels elevated by 28 and $24 \%$ respectively. 


\subsection{Discussion and Conclusion}

240 Unlike conventional brewer's yeast, the proteins, amino acids, energy and other nutrients (e.g. vitamins and trace metals) can be found bounded to the cell wall. Consequently, this would result in in a lower nutrient digestibility for fish (Ferreira et al., 2010; Shurson, 2018). In contrast, autolysed brewer's yeast would have the cell wall degraded, thereby increasing nutrient bioavailability and potentially having higher bioactivity. The potential of autolysed brewer's yeast to enhance growth performance was confirmed in this study, with improved final body weight and metabolic growth rate. This was particularly evident in African catfish fed with a diet that has $3 \mathrm{~g} \mathrm{~kg}^{-1}$ autolysed brewer's yeast inclusion. The findings in this study concur with the results in the feeding trial study of Yuan et al., (2017) on Jian carp (Cyprinus carpio var. Jian) using hydrolysed yeast. The authors reported that $30 \mathrm{~g} \mathrm{~kg}^{-1}$ inclusion of yeast hydrolysate resulted in significantly improved fish final weight and weight gain by up to 21 and $24 \%$, respectively. This ten-fold difference in brewer's yeast inclusion level between the feeding trials, could be the result of varying manufacturing processes being used to produce the degraded brewer's yeast. In contrast, largemouth bass (M. salmoides) fed with diets supplemented with lower levels up to $2 \mathrm{~g} \mathrm{~kg}^{-1}$ hydrolysed yeast showed no enhancements in growth performance, feed efficiency or morphometric parameters (Zhou et al., 2018).

Haematological parameters of fish species are useful tools for assessing the health status and function of internal organs. In this present study, the measured haematological parameters showed that there were no discernible changes in the fish health or welfare (e.g. white blood cells count and white blood cells differentiation), regardless of whether the fish received dietary autolysed brewer's yeast. The health of the liver can be assessed by several key enzyme activities both in the organ and in the blood (e.g. aspartate transaminase, AST; alanine transaminase, ALT; alkaline phosphatase, ALP). Basically, ALT and AST function in transferring amine groups in trans-amination reactions in liver for non-essential amino acid synthesis and de-amination pathways. Aspartate aminotransferase (AST) catalyses a key metabolic step of the molecular rearrangement involving amino acids associated with the citric acid cycle (ketogenic) whereas alanine aminotransferase (ALT) predominates in tissues and organs with intensive gluconeogenesis, such as in the liver (Urich, 1994; Torre et al., 2000). The determination of plasma or serum enzyme activity levels of alanine-amino transferase (ALT) and aspartate-amino transferase (AST) and alkaline phosphatase (ALP) may be indicative of hepatic function and status in animals including fish. Hence, ALT and AST are 
in humans and animals. Elevations in the serum AST and ALT enzyme activity can indicate

273 liver damage or inflammation to environmental contaminants, disease, stress and nutrients

274 (Wan et al., 2016). For the current study, catfish fed diets supplemented with $3 \mathrm{~g} \mathrm{~kg}^{-1} \mathrm{or} \mathrm{g}$

$275 \mathrm{~kg}^{-1}$ yeast autolysate showed significantly lower serum ALT activity but not at the highest level 276 of $10 \mathrm{~g} \mathrm{Kg}^{-1}$ inclusion rate. Since ALT was lowered in plasma of catfish fed dietary autolysed 277 yeast, it may be inferred that this natural and bioactive supplement could help protect the membrane integrity of the liver cells and optimize hepatic function within a specific range. Dimitroglou et al. (2010) reported enhancement the intestinal system integrity and immune function by yeast fraction components (i.e. $\beta$-glucans and MOS) in other species like sea bream. Future work will test this hypothesis in more detail to examine hepatic function of catfish fed AY in terms of both histomorphology and histocytochemistry for selected enzyme activities.

284 Also, the current study showed a trend for elevated serum AST and ALP. However, although not deemed to be statistically significant due to high variation in the data, these enzyme activities were higher in the control diet without hydrolysed yeast. We know that yeast contains quite high levels of nucleotides that may affect metabolism in animals and fish. It might be interesting in a future study to test if yeast nucleotides can be assimilated with liver hepatocytes and raise protein synthesis and metabolism and thus leading to enzyme activation of ALT, AST, and ALP. These may show some leakage into the systemic circulation of the catfish but may not be due to liver impairment per se. Exogenous dietary nucleotides as found in yeast play an important role in the repair and regeneration of damage in liver; since deprivation of nucleotides significantly reduces the hepatic protein synthesis rate as shown in the cirrhotic rat model by Perez et al. (2004).

Factors such as stress, contaminants, and diets can all play a role in disrupting the normal morphology and function of the gut. A deterioration in alimentary canal exposes the fish to opportunistic pathogens as an entry site to gain access to the rest of the body (Segner et al., 2012). The current study observed that the perimeter ratio of catfish mid-intestine (indicative of surface for nutrient absorption) remained unchanged when fed with brewer's yeast autolysate. However, the abundance of mucous-secreting goblet cells in the mid-intestine were significantly elevated compared to those catfish that were not fed with yeast supplementation. This could suggest that autolysed yeast supplemented diets could enhance the intestinal barrier interface secretory dynamics of the catfish as in other fish species (Sweetman et al. 2010). The observed increase in the number of goblet cells found in the current study was comparable to the results reported by Zhu et al. (2012). The authors found that $40 \mathrm{~g} \mathrm{~kg}^{-1}$ dietary 
supplementation of yeast polysaccharides in channel catfish (I. punctatus) increased goblet cells count by up to $40 \%$. It was also reported that the channel catfish had higher intestinal folds in yeast polysaccharide supplementation treatment groups, which was not observed in the present study by the perimeter ratio of mid-intestine measurements.

The morphological examination of the catfish gut revealed there were enhancements in the abundance of intraepithelial leucocytes (a component of gut-associated lymphoid tissue) and goblet cells in autolysed yeast supplemented dietary group. This could be attributed to the higher exposure of nutraceutical compounds (e.g. $\beta$-glucans, mannan-oligosaccharides and nucleotides) present in the degraded cell wall of autolysed brewer's yeast. Furthermore, the trends in the proliferation of goblet cells and IELs in AY supplemented groups might be associated with increased immune response, however, further study is required to validate this assertion. While the present study has shown brewer's yeast hydrolysate can affect the physiological function of the fish intestinal tract, Zhou et al. (2018) found that degraded yeast can also decrease several potential pathogen species (Plesiomonas, Mycoplasmas, Synechococcus and Peptostreptococcus) in the gut of largemouth bass. Further assessment on effects of autolysed yeast on African catfish gut microbiome would be warranted, in order to fully appraise this functional feed ingredient as an enhancer of gut robustness.

It could be concluded from this feeding study that dietary supplementation of autolysed brewer's yeast can improve growth performance and enhance intestinal morphology in African catfish, $C$. gariepinus. This can have important consequences in the health management of the species in intensive production systems. The use of prophylactic farming strategies associated with enriched diet formulations using autolysed brewer's yeast would not impair the liver function and may mitigate husbandry-related and environmental stresses. This will help to minimise the use of therapeutic agents with obvious economic and environmental benefits for this important farmed fish species in Africa and other parts of the African catfish farming regions of the world as in Asia for related species.

\subsection{References}

Abdel-Tawwab, M., Adeshina, I., Jenyo-Oni, A., Ajani, E. K., \& Emikpe, B. O. (2018). Growth, physiological, antioxidants, and immune response of African catfish, Clarias gariepinus (B.), to dietary clove basil, Ocimum gratissimum, leaf extract and its susceptibility to Listeria monocytogenes infection. Fish and Shellfish Immunology, 78, 346-354. https://doi.org/10.1016/j.fsi.2018.04.057

Adeoye, A. A., Yomla, R., Jaramillo-Torres, A., Rodiles, A., Merrifield, D. L., \& Davies, S. J. 
(2016). Combined effects of exogenous enzymes and probiotic on Nile tilapia (Oreochromis niloticus) growth, intestinal morphology and microbiome. Aquaculture, 463, 61-70. https://doi.org/10.1016/j.aquaculture.2016.05.028

Amir, I., Zuberi, A., Imran, M., \& Ullah, S. (2018). Evaluation of yeast and bacterial based probiotics for early rearing of Labeo rohita (Hamilton, 1822). Aquaculture Research, 49(12), 3856-3863. https://doi.org/10.1111/are.13852

AOAC (2012). Official methods of analysis of the Association of Official Analytical Chemists, 19th edn. Association of Official Analytical Chemists, Inc., USA

Bain, B., Bates, I., Laffan M. A, (2017). Dacie and Lewis, Practical haematology. $12^{\text {th }}$ edition. Elsevier, Amsterdam, Netherlands.

Bondad-Reantaso, M. G., Subasinghe, R. P., Arthur, J. R., Ogawa, K., Chinabut, S., Adlard, R., Tanz, Z., Shariff, M. (2005). Disease and health management in Asian aquaculture. Veterinary Parasitology, 132(3-4), 249-272. https://doi.org/10.1016/j.vetpar.2005.07.005

Dawood, M.A.O., Koshio, S., Ishikawa, M., Yokoyama, S., El Basuini, M. F., Hossain, M. S., Nhu T. H., Moss., Dossou, S., Wei, H. (2017). Dietary supplementation of $\beta$-glucan improves growth performance, the innate immune response and stress resistance of red sea bream, Pagrus major. Aquaculture Nutrition, 23(1), 148-159. https://doi.org/10.1111/anu.12376

Dawood, Mahmoud A.O., Koshio, S., \& Esteban, M. Á. (2018). Beneficial roles of feed additives as immunostimulants in aquaculture: a review. Reviews in Aquaculture, 10(4), 950-974. https://doi.org/10.1111/raq.12209

Dimitroglou, A., Merrifield, D. L., Spring, P., Sweetman, J., Moate, R., \& Davies, S. J. (2010). Effects of mannan oligosaccharide (MOS) supplementation on growth performance, feed utilisation, intestinal histology and gut microbiota of gilthead sea bream (Sparus aurata). Aquaculture, 300(1), 182-188. https://doi.org/10.1016/j.aquaculture.2010.01.015

Ezenwaji, N. E., Ada, I., Chinedu, A., Chukwuemeka, O. N., \& Chioma, U. N. (2012). Substitution of soyabean meal with bioactive yeast in the diet of Clarias gariepinus: Effect on growth rate, haematological and biochemical profile. African Journal of Biotechnology, 11(91), 15802-15810. https://doi.org/10.5897/AJB12.771

FAO. (2018). World Fisheries and Aquaculture. The State of World Fisheries and Aquaculture 2018 - Meeting the sustainable development goals. Food and Agriculture Oraganization of the United Nations, Rome (Vol. 35). Available from https://doi.org/issn 10 [accessed on $20 / 05 / 19$ ] 
FAO (2019). Global aquaculture production. Food and Agriculture Oraganization of the United Nations, Rome. Available from http://www.fao.org/fishery/statistics/global-aquacultureproduction/en [Accessed on 20/05/19]

Fawole, F. J., Sahu, N. P., Shamna, N., Phulia, V., Emikpe, B. O., Adeoye, A. A., Aderolu, A.Z., Popoola, O. M. (2018). Effects of detoxified Jatropha curcas protein isolate on growth performance, nutrient digestibility and physio-metabolic response of Labeo rohita fingerlings. Aquaculture Nutrition, 24(4), 1223-1233. https://doi.org/10.1111/anu.12660

Ferreira, I. M. P. L. V. O., Pinho, O., Vieira, E., Tavarela, J. G. (2010). Brewer's Saccharomyces yeast biomass: characteristics and potential applications. Trends in food science \& technology, 21, 77-84.

Gultepe, N., Salnur, S., Hossu, B., \& Hisar, O. (2011). Dietary supplementation with Mannanoligosaccharides (MOS) from Bio-Mos enhances growth parameters and digestive capacity of gilthead sea bream (Sparus aurata). Aquaculture Nutrition, 17(5), 482-487. https://doi.org/10.1111/j.1365-2095.2010.00824.x

Hassaan, M. S., Mahmoud, S. A., Jarmolowicz, S., El-Haroun, E. R., Mohammady, E. Y., \& Davies, S. J. (2018). Effects of dietary baker's yeast extract on the growth, blood indices and histology of Nile tilapia (Oreochromis niloticus L.) fingerlings. Aquaculture Nutrition, 24(6), 1709-1717. https://doi.org/10.1111/anu.12805

Hoffman, L. C., Prinsloo, J. F., \& Rukan, G. (1997). Partial replacement of fish meal with either soybean meal, brewers yeast or tomato meal in the diets of African sharptooth catfish Clarias gariepinus. Water SA, 23(2), 181-186. Journals/Manuscripts/1997/02/WaterSA_1997_02_1009.PDF [Accessed on 20/05/19]

Huyben, D., Nyman, A., Vidaković, A., Passoth, V., Moccia, R., Kiessling, A., Dicksved, J., Lundh, T. (2017). Effects of dietary inclusion of the yeasts Saccharomyces cerevisiae and Wickerhamomyces anomalus on gut microbiota of rainbow trout. Aquaculture, 473, 528537. https://doi.org/10.1016/J.AQUACULTURE.2017.03.024

Jin, M., Xiong, J., Zhou, Q.-C., Yuan, Y., Wang, X.-X., \& Sun, P. (2018). Dietary yeast hydrolysate and brewer's yeast supplementation could enhance growth performance, innate immunity capacity and ammonia nitrogen stress resistance ability of Pacific white shrimp (Litopenaeus vannamei). Fish \& Shellfish Immunology, 82, 121-129. https://doi.org/10.1016/J.FSI.2018.08.020

Kemigabo, C., Jere, L. W., Sikawa, D., Masembe, C., \& Kang, J. (2019). Growth response of African catfish, Clarias gariepinus ( B .), larvae and fingerlings fed protease-incorporated diets. Journal of Applied Ichthyology, 35: 480 - 487. https://doi.org/10.1111/jai.13877

Kiron, V. (2012). Fish immune system and its nutritional modulation for preventive health 
care. Animal Feed Science and Technology, 173(1-2), 111-133. https://doi.org/10.1016/J.ANIFEEDSCI.2011.12.015

Li, P., \& Gatlin, D. M. (2003). Evaluation of brewers yeast (Saccharomyces cerevisiae) as a feed supplement for hybrid striped bass (Morone chrysops x M. saxatilis). Aquaculture, 219(1-4), 681-692. https://doi.org/10.1016/S0044-8486(02)00653-1

Librán-Pérez, M., Costa, M. M., Figueras, A., \& Novoa, B. (2018). $\beta$-glucan administration induces metabolic changes and differential survival rates after bacterial or viral infection in turbot (Scophthalmus maximus). Fish and Shellfish Immunology, 82, 173-182. https://doi.org/10.1016/j.fsi.2018.08.005

Liu, Z., Que, S., Xu, J., Peng, T. (2014). Alanine aminotransferase-old biomarker and new concept: a review. International Journal Of Medical Sciences, 11, 925.

Momeni-Moghaddam, P., Keyvanshokooh, S., Ziaei-Nejad, S., Parviz Salati, A., \& PashaZanoosi, H. (2015). Effects of mannan oligosaccharide supplementation on growth, some immune responses and gut lactic acid bacteria of common carp (Cyprinus Carpio) fingerlings. Veterinary Research Forum, 6(3), 239-244. Retrieved from https://www.ncbi.nlm.nih.gov/pmc/articles/PMC4611979/

Nyang'ate Onura, C., Van den Broeck, W., Nevejan, N., Muendo, P., \& Van Stappen, G. (2018). Growth performance and intestinal morphology of African catfish (Clarias gariepinus, Burchell, 1822) larvae fed on live and dry feeds. Aquaculture, 489, 70-79. https://doi.org/10.1016/J.AQUACULTURE.2018.01.046

Oké, V., \& Goosen, N. J. (2019). The effect of stocking density on profitability of African catfish (Clarias gariepinus) culture in extensive pond systems. Aquaculture, 507, 385392. https://doi.org/10.1016/J.AQUACULTURE.2019.04.043

Ozório, R. O. A., Portz, L., Borghesi, R., \& Cyrino, J. E. P. (2012). Effects of dietary yeast (Saccharomyces cerevisia) supplementation in practical diets of tilapia (Oreochromis niloticus). Animals, 2(1), 16-24. https://doi.org/10.3390/ani2010016

Peterson, B. C., Booth, N. J., Barrows, F. T., \& Manning, B. B. (2012). Improved survival in channel catfish fed mannanoligosaccharides in an extruded diet. Open Journal of Animal Sciences, 2(2), 57-61. https://doi.org/10.4236/ojas.2012.22009

Pilarski, F., Ferreira de Oliveira, C. A., Darpossolo de Souza, F. P. B., \& Zanuzzo, F. S. (2017). Different $\beta$-glucans improve the growth performance and bacterial resistance in Nile tilapia. Fish and Shellfish Immunology, 70, 25-29. https://doi.org/10.1016/j.fsi.2017.06.059

Pongpet, J., Ponchunchoovong, S., \& Payooha, K. (2016). Partial replacement of fishmeal by 
brewer's yeast (Saccharomyces cerevisiae) in the diets of Thai Panga (Pangasianodon hypophthalmus $\times$ Pangasius bocourti). Aquaculture Nutrition, 22(3), 575-585. https://doi.org/10.1111/anu.12280

Prasad, L., Nayak, B. B., Srivastava, P. P., Reddy, A. K., \& Kohli, M. P. S. (2013). Use of brewer's yeast Saccharomyces cerevisiae as growth promoter in giant freshwater prawn (Macrobrachium rosenbergii de man) post larvae. Turkish Journal of Fisheries and Aquatic Sciences, 13(3), 447-452. https://doi.org/10.4194/1303-2712-v13_3_07

Qiu, X., \& Davis, D. A. (2017). Evaluation of flash dried yeast as a nutritional supplement in plant-based practical diets for Pacific white shrimp Litopenaeus vannamei. Aquaculture Nutrition, 23(6), 1244-1253. https://doi.org/10.1111/anu.12499

Sado, Ricardo Y., Bicudo, Á. J. A., \& Cyrino, J. E. P. (2014). Growth and intestinal morphology of juvenile pacu Piaractus mesopotamicus (Holmberg 1887) fed dietary prebiotics (mannanoligosaccharides-MOS). Anais Da Academia Brasileira de Ciencias, 86(3), 1517-1524. https://doi.org/10.1590/0001-3765201420130088

Sado, Ricardo Yuji, Bicudo, Á. J. D. A., \& Cyrino, J. E. P. (2008). Feeding dietary mannan oligosaccharides to juvenile Nile tilapia, Oreochromis niloticus, has no effect on hematological parameters and showed decreased feed consumption. Journal of the World Aquaculture Society, 39(6), 821-826. https://doi.org/10.1111/j.1749-7345.2008.00219.x

Salem, M., Gaber, M. M., Zaki, M. A. dal, \& Nour, A. A. (2016). Effects of dietary mannan oligosaccharides on growth, body composition and intestine of the sea bass (Dicentrarchus labrax L.). Aquaculture Research, 47(11), 3516-3525. https://doi.org/10.1111/are.12801

Segner, H., Sundh, H., Buchmann, K., Douxfils, J., Sundell, K.S., Mathieu, C., Ruane, N., Jutfelt, F., Toften, H., Vaughan, L. (2012). Health of farmed fish: its relation to fish welfare and its utility as welfare indicator. Fish physiology and biochemistry, 38, 85-105.

Shurson, G. C. (2018). Yeast and yeast derivatives in feed additives and ingredients: Sources, characteristics, animal responses, and quantification methods. Animal Feed Science and Technology, 235, 60-76. https://doi.org/10.1016/J.ANIFEEDSCI.2017.11.010

Solomon, S. G., Ataguba, G. A., \& Itodo, G. E. (2017). Performance of Clarias gariepinus Fed Dried Brewer's Yeast (Saccharomyces cerevisiae) Slurry in Replacement for Soybean Meal. Journal of Nutrition and Metabolism, 2017, 1-8. https://doi.org/10.1155/2017/8936060

Torrecillas, S., Makol, A., Caballero, M. J., Montero, D., Robaina, L., Real, F., Sweetman, J., Tort, L., Izquierdo, M. S. (2007). Immune stimulation and improved infection resistance in European sea bass (Dicentrarchus labrax) fed mannan oligosaccharides. Fish and 
United Nations (2017). World population prospects: the 2017 revision. World Population Prospects: The 2017 revision, Key Findings and Advance Tables. Department of

Zhang, P., Cao, S., Zou, T., Han, D., Liu, H., Jin, J., Yang, Y., Zhu, X., Xie, S., Zhou, W. (2018). Effects of dietary yeast culture on growth performance, immune response and disease resistance of gibel carp (Carassius auratus gibelio CAS III). Fish and Shellfish Immunology, 82, 400-407. https://doi.org/10.1016/j.fsi.2018.08.044

Zhou, M., Liang, R., Mo, J., Yang, S., Gu, N., Wu, Z., Babu, S., Li, J., Haung, Y., Lin, L. (2018). Effects of brewer's yeast hydrolysate on the growth performance and the intestinal bacterial diversity of largemouth bass (Micropterus salmoides). Aquaculture, 484, 139144. https://doi.org/10.1016/j.aquaculture.2017.11.006

Zhu, H., Liu, H., Yan, J., Wang, R., Liu, L. (2012). Effect of yeast polysaccharide on some hematologic parameter and gut morphology in channel catfish (Ictalurus punctatus). Fish Physiol Biochem, 38(5), 1441-7. doi: 10.1007/s10695-012-9631-3

\section{Data Availability Statement}


559 The data published in this research study is available upon reasonable request from the 560 corresponding author, adeoyeaa@funaab.edu.ng.

561 


\section{Tables}

563 Table 1. Nutritional composition of autolysed brewer's yeast ( $\mathrm{g} \mathrm{kg}^{-1}$, dry weight) Variables $\left(\mathrm{g} \mathrm{kg}^{-1}\right)$ Autolysed brewer's yeast

Crude protein 500.00

Crude oils and fats 30.00

Crude fibre 10.00

Crude ash 66.00

Lysine 36.00

Methionine 8.00

Glutathione 6.00

Choline

Nucleic acid protein (in CP) 120.00

564 The autolysed brewer's yeast (Leiber $\mathrm{CeFi}^{\circledR}$ Pro) was supplied by Leiber $\mathrm{GmbH}$, Bramsche, 565 Germany 
Table 2. Formulation and composition of the experimental diets $\left(\mathrm{g} \mathrm{kg}^{-1}\right.$, dry weight)

\begin{tabular}{lrrrr}
\hline Ingredients $\left(\mathrm{g} \mathrm{kg}^{-1}\right)$ & Control & 3-AY & 6-AY & 10-AY \\
\hline Fish meal $(72 \% \mathrm{CP})^{\mathrm{a}}$ & 100.00 & 100.00 & 100.00 & 100.00 \\
Poultry meal $(66 \% \mathrm{CP})^{\mathrm{a}}$ & 200.00 & 200.00 & 200.00 & 200.00 \\
Shrimp meal $(56 \% \mathrm{CP})^{\mathrm{a}}$ & 50.00 & 47.00 & 44.00 & 40.00 \\
${\text { Soybean meal }(45 \% \mathrm{CP})^{\mathrm{a}}}$ & 350.00 & 350.00 & 350.00 & 350.00 \\
Maize flour $^{\mathrm{a}}$ & 200.00 & 200.00 & 200.00 & 200.00 \\
Vegetable oil $^{\mathrm{a}}$ & 79.90 & 79.90 & 79.90 & 79.90 \\
Vitamin mineral premix $^{\mathrm{b}}$ & 10.00 & 10.00 & 10.00 & 10.00 \\
Autolysed brewer's yeast & 0.00 & 3.00 & 6.00 & 10.00 \\
Anti-oxidant & 0.10 & 0.10 & 0.10 & 0.10 \\
Binder (Cassava starch) $_{\text {Total }}$ & 10.00 & 10.00 & 10.00 & 10.00 \\
& 1000.00 & 1000.00 & 1000.00 & 1000.00
\end{tabular}

Composition ( $\mathrm{g} \mathrm{kg}^{-1}$, dry weight)

Dry matter

$\begin{array}{rrrr}906.70 & 908.70 & 904.70 & 907.30 \\ 389.00 & 389.00 & 386.00 & 391.80 \\ 136.00 & 137.00 & 133.00 & 139.00 \\ 65.50 & 68.40 & 69.60 & 67.90 \\ 361.00 & 356.00 & 356.00 & 357.00 \\ 43.90 & 43.50 & 49.40 & 40.20\end{array}$

Crude protein

49.40

40.20

angredients were sourced from local feed ingredients' market (ABMN LTD, Ibadan, Nigeria). ${ }^{\text {b Vitamin mineral }}$ premix contains (per 2.5kg) 20,000,000IU vitamin A, 4,000,000IU vitamin D3, 200,000 vitamin E, 8,000mg vitamin K3, 20,500mg vitamin B1, 15,000 mg vitamin B2, 19,500 mg vitamin B6, 15mcg vitamin B12, 90,000 mg Nicotinic Acid, 40,000 mg Pantothenic Acid, $500 \mathrm{mg}$ Folic Acid, 600,000 mcg Biotin, 40,000 mg Choline Chloride, 4,000 mg Iron, $500 \mathrm{mg}$ Copper, 30,000 mg Manganese, 40,000 mg Zinc, 2,000 mg Iodine, $200 \mathrm{mcg}$ Selenium, 300,000 mg coated Vitamin C, 50,000 mg Inositol, $750 \mathrm{mg}$ Cobalt, 50,000 mg Lysine, 50,000 mg Methionine and 125,000 mg Antioxidant. CP, crude protein. 
576 Table 3. Growth, feed efficiency and somatic indices of African catfish fed diets containing 577 different levels of autolysed brewer's yeast (AY) for 49 days $(n=3, \pm \mathrm{SD})$

\begin{tabular}{lcccc}
\hline & Control & 3-AY & 6-AY & 10-AY \\
\hline IBW $\left(\mathrm{g} \mathrm{fish}^{-1}\right)$ & $22.00 \pm 0.71$ & $22.20 \pm 0.85$ & $23.50 \pm 1.41$ & $22.30 \pm 0.47$ \\
FBW $\left(\mathrm{g} \mathrm{fish}^{-1}\right)$ & $91.00 \pm 1.90^{\mathrm{a}}$ & $106.05 \pm 6.46^{\mathrm{b}}$ & $98.12 \pm 8.21^{\mathrm{ab}}$ & $98.01 \pm 8.21^{\mathrm{ab}}$ \\
Feed intake $\left(\mathrm{g} \mathrm{fish}^{-1}\right)$ & $90.69 \pm 10.11$ & $91.16 \pm 4.68$ & $87.48 \pm 6.10$ & $88.73 \pm 2.41$ \\
MWG $\left(\mathrm{g} \mathrm{fish}^{-1}\right)$ & $72.37 \pm 3.65$ & $84.18 \pm 5.94$ & $76.34 \pm 4.80$ & $78.40 \pm 6.10$ \\
PWG $(\%)$ & $301.74 \pm 22.52$ & $374.03 \pm 31.20$ & $309.98 \pm 29.21$ & $306.30 \pm 52.39$ \\
SGR $\left(\%\right.$ day $\left.^{-1}\right)$ & $2.90 \pm 0.03$ & $3.19 \pm 0.11$ & $2.92 \pm 0.12$ & $3.01 \pm 0.19$ \\
MGR $\left(\mathrm{g} \mathrm{kg}^{-0.8}\right.$ day $\left.^{-1}\right)$ & $14.51 \pm 0.08^{\mathrm{a}}$ & $16.01 \pm 0.54^{\mathrm{b}}$ & $14.80 \pm 0.47^{\mathrm{ab}}$ & $15.12 \pm 0.91^{\mathrm{ab}}$ \\
FCR & $1.25 \pm 0.12$ & $1.08 \pm 0.02$ & $1.15 \pm 0.10$ & $1.14 \pm 0.06$ \\
PER & $1.53 \pm 0.15$ & $1.82 \pm 0.06$ & $1.67 \pm 0.18$ & $1.70 \pm 0.13$ \\
Condition factor & $0.72 \pm 0.07$ & $0.84 \pm 0.10$ & $0.82 \pm 0.09$ & $0.81 \pm 0.10$ \\
HSI & $1.06 \pm 0.11$ & $1.12 \pm 0.16$ & $1.30 \pm 0.12$ & $1.18 \pm 0.22$ \\
VSI & $10.19 \pm 1.15^{\mathrm{a}}$ & $11.55 \pm 1.44^{\mathrm{ab}}$ & $10.87 \pm 1.67^{\mathrm{ab}}$ & $12.95 \pm 0.54^{\mathrm{b}}$ \\
Survival $(\%)$ & $91.67 \pm 4.71$ & $98.33 \pm 2.36$ & $95.00 \pm 0.00$ & $86.67 \pm 8.50$
\end{tabular}

Values with different superscripts on the same row indicates there is a significant difference $(P<0.05)$. IBW,

579 initial mean body weight; FBW, final mean body weight; MWG, mean weight gain; PWG, percentage weight gain; SGR, specific growth rate; MGR, metabolic growth rate; FCR, feed conversion ratio; PER, protein efficient ratio; HSI, hepatosomatic index; VSI, viscerosomatic index. 
Table 4. Haematological-biochemical parameters of African catfish fed diets containing different levels of autolysed brewer's yeast (AY) for 49 days $(n=3, \pm \mathrm{SD})$

\begin{tabular}{lcccc}
\hline & Control & 3-AY & 6-AY & 10-AY \\
\hline PCV (\%) & $35.00 \pm 2.78$ & $36.30 \pm 1.76$ & $35.50 \pm 1.00$ & $37.30 \pm 1.04$ \\
Haemoglobin $\left(\mathrm{g} \mathrm{dL}^{-1}\right)$ & $11.70 \pm 0.98$ & $12.30 \pm 0.65$ & $11.90 \pm 0.36$ & $12.50 \pm 0.31$ \\
RBC $\left(10^{12} \mathrm{~L}^{-1}\right)$ & $2.50 \pm 0.45$ & $2.55 \pm 0.13$ & $2.40 \pm 0.18$ & $2.86 \pm 0.43$ \\
WBC $\left(10^{9} \mathrm{~L}^{-1}\right)$ & $143.00 \pm 24.40$ & $101.00 \pm 64.80$ & $208.00 \pm 82.20$ & $113.00 \pm 66.90$ \\
Neutrophil (\%) & $24.60 \pm 6.45$ & $23.20 \pm 7.77$ & $24.40 \pm 3.61$ & $27.00 \pm 11.70$ \\
Lymphocytes (\%) & $72.20 \pm 6.43$ & $68.30 \pm 8.13$ & $71.50 \pm 3.12$ & $70.50 \pm 11.40$ \\
Basophil (\%) & $0.67 \pm 0.76$ & $0.33 \pm 0.58$ & $0.67 \pm 0.76$ & $0.33 \pm 0.58$ \\
Eosinophil (\%) & $1.50 \pm 1.32$ & $2.00 \pm 1.50$ & $2.00 \pm 1.73$ & $1.00 \pm 0.76$ \\
Monocytes (\%) & $3.50 \pm 1.80$ & $2.17 \pm 1.76$ & $3.83 \pm 0.76$ & $2.83 \pm 0.29$ \\
MCV (fL) & $144.00 \pm 23.1$ & $142.00 \pm 0.40$ & $149.00 \pm 9.77$ & $133.00 \pm 16.3$ \\
MCH (pg) & $48.40 \pm 7.38$ & $48.20 \pm 0.26$ & $50.00 \pm 3.58$ & $44.80 \pm 5.51$ \\
MCHC (g dL $\left.{ }^{-1}\right)$ & $33.60 \pm 0.54$ & $33.80 \pm 0.26$ & $33.50 \pm 0.24$ & $33.60 \pm 0.15$ \\
AST (IU L $\left.{ }^{-1}\right)$ & $160.00 \pm 19.70$ & $174.00 \pm 14.60$ & $146.00 \pm 19.60$ & $185.00 \pm 32.00$ \\
ALT (IU L $\left.{ }^{-1}\right)$ & $24.90 \pm 2.17^{\mathrm{a}}$ & $15.70 \pm 3.9^{\mathrm{c}}$ & $16.80 \pm 1.53^{\mathrm{bc}}$ & $22.40 \pm 2.67^{\mathrm{ab}}$ \\
ALP (IU L $\left.{ }^{-1}\right)$ & $60.00 \pm 8.40$ & $62.70 \pm 12.50$ & $75.70 \pm 15.20$ & $69.80 \pm 11.60$
\end{tabular}

Values with different superscripts on the same row indicates there is a significant difference $(P<0.05)$. PCV, packed cells volume; RBC, red blood cells; WBC, leucocytes; \%, mean percentage of total leucocytes; MCV, mean corpuscular volume; MCH, mean corpuscular haemoglobin; MCHC, mean corpuscular haemoglobin concentration; AST, aspartate transaminase (IU L ${ }^{-1}$ ); ALT, alanine transaminase (IU $\mathrm{L}^{-1}$ ); ALP, alkaline phosphatase (IU L-1) 
Table 5. Intestinal histology of African catfish fed diets containing different levels of autolysed brewer's yeast (AY) for 49 days $(n=3, \pm \mathrm{SD})$

\begin{tabular}{lcccc}
\hline & Control & 3-AY & 6-AY & 10-AY \\
\hline Perimeter ratio (AU) & $2.93 \pm 0.63$ & $3.12 \pm 0.87$ & $2.30 \pm 0.60$ & $3.24 \pm 1.51$ \\
Goblet cells (per 100 $\mu \mathrm{m})$ & $4.78 \pm 0.87^{\mathrm{a}}$ & $5.75 \pm 1.49^{\mathrm{b}}$ & $6.32 \pm 1.28^{\mathrm{c}}$ & $6.62 \pm 1.28^{\mathrm{c}}$ \\
IELs (per 100 $\mu \mathrm{m})$ & $42.00 \pm 7.33^{\mathrm{a}}$ & $47.94 \pm 7.87^{\mathrm{b}}$ & $53.71 \pm 8.23^{\mathrm{c}}$ & $53.36 \pm 9.56^{\mathrm{c}}$ \\
\hline
\end{tabular}

Values with different superscripts on the same row indicates there is a significant difference $(P<0.05)$. AU, arbitrary units and IELs, Intraepithelial leucocytes 


\section{Figure Legend}

Figure 1. Light micrograph of the mid-intestine of African catfish fed the Control (a), $3 \mathrm{~g} \mathrm{~kg}^{-}$ ${ }^{1} \mathrm{AY}$ (b), $6 \mathrm{~g} \mathrm{~kg}^{-1} \mathrm{AY}$ (c) and $10 \mathrm{~g} \mathrm{~kg}^{-1} \mathrm{AY}$ (d) diets; Goblet cells (arrows) and abundant IELs (arrowheads) are present in the epithelia. Abbreviations are E enterocytes, LP lamina propria and L lumen. Light microscopic staining: Periodic Acid Schiff, scale bar $=100 \mu \mathrm{m}$

JW Sweetman, S Torrecillas, A Dimitroglou, S Rider, SJ Davies, Enhancing the natural defences and barrier protection of aquaculture species (2010) Aquaculture Research 41 (3), 345-355

A Dimitroglou, SJ Davies, J Sweetman, P Divanach, S Chatzifotis (2010) Dietary supplementation of mannan oligosaccharide on white sea bream (Diplodus sargus L.) larvae: effects on development, gut morphology and salinity tolerance Aquaculture Research 41 (9), 245-25 